bevidsthed om samfundet og dets muligheder, før den enkelte ved viljeshandlinger kunne påtage sig medansvar for samfundets trivsel og udvikling og dermed frivilligt påtage sig folkefællesskabet.

Forfatteren har i bogen påvist en sådan kontinuitet gennem 200 år - andre ville kunne pege på brudflader og diskontinuitet.

Tine Damsholt har skrevet en lille bog af stor betydning for forståelsen af dansk politisk kultur.

\title{
Den nordiske mytologi, folkehøjskolen og livsoplysningen
}

\section{Af Kim Arne Pedersen}

Jens Peter Agidius: Vølvens Spådom på dansk. En litteratur - og åndshistorisk undersøgelse. Studier fra Sprog - og Oldtidsforskning. København 1978. 137 s.

Jens Peter Agidius: Bragesnak 1. Nordiske Myter og Mytefortalling i Dansk Tradition (indtil 1910). Odense Universitetsforlag. Odense 1985. 255 s. 99 kr.

Jens Peter Agidius: Bragesnak 2. Den mytologiske tradition i dansk folkeoplysning. Odense Universitetsforlag. Odense 1992. 270 s. 240 kr.

Jens Peter Agidius: Christian Flor. Padagogen, politikeren, folkeoplyseren. En biografi. Odense Universitetsforlag 1994. 386 s. $250 \mathrm{kr}$.

Blandt de mange bøger, som er fremkommet i forbindelse med højskolejubilæet $\mathrm{i}$ 1994, finder vi også en omfattende og grundig skildring af Rødding højskoles stifter og leder, det danske sprogs forkæmper Christian Flor. Forfatteren til dette værk er Jens Peter Ægidius, magister i nordisk litteratur ved Odense Universitet, senere forsker sammesteds og i en periode dansk lektor i Kiel, - og dermed indehaver af et embede, der peger tilbage til Flors stilling ved samme universitet over hundrede år tidligere. Ægidius har indledt sin forskerkarriere midtvejs i livet, men har alligevel formået at udsende en række værker, der fremstiller den nordiske mytologis rolle $\mathrm{i}$ dansk åndsliv fra det 18. århundrede og frem til i dag. Det er imidlertid ikke kun på baggrund af den sent indledte karriere, disse værker imponerer. Ægidius’’ bøger vidner om hans omfattende viden og om evne til at gøre denne viden tilgængelig i en klar og fast form, uden at der gives køb, når det drejer sig om kildemæssigt belæg og omhu for detaljen. Ægidius er god til at få de mange oplysninger med, så god, at hans fremstillinger $\mathrm{i}$ ny og næ tenderer mod den kronologisk ordnede materialesamling.

Det ville dog være forkert at hævde, at Ægidius’ forskning ikke er båret af et samlende synspunkt. Det fremgår af adskillige tekstsammenhænge i hans bøger, at Ægidius personligt føler sig forpligtet på romantikkens interesse for det oprindelige, 
for de grundværdier, der kommer til udtryk i og gennem den folkelige, mundtlige tradition, og at han selv følger, hvad der kan betegnes som en Grundtvig-inspireret opfattelse af myterne og muligheden for at lade myternes aktuelle brug danne udgangspunkt for livsoplysning. Ægidius kan skrive med sympati om romantikken som den strømning, der åbner for adgangen til det ubevidste og samtidig stiller mennesket $\mathrm{i}$ et valg mellem dette livsgrundlag og det, der står det imod.

Ægidius’s forskning følger fra begyndelsen to spor. Ægidius har selv været en flittig oversætter, og i 1978 udkom bogen Vølvens Spådom på dansk, et værk, der undersøger oversættelsen af netop dette Edda-digt som »en enkelt tråd i et stort mønster, det store mønster som hedder dansk kultur og åndsliv i videre forstand i perioden fra omkring 1780 frem til i dag « (8). Bogen indeholder en imponerende kortlægning af samtlige oversættelser, både de fulde oversættelser og brudstykkerne. Oversættelsesproblematikken dominerer bogen, men åndshistorien glemmes derfor ikke. Ægidius redegør for Grundtvigs brug af Edda-citater i både det tidlige og det modne forfatterskab, og får således mulighed for at behandle Grundtvigs varierede mængde af oversættelser af den samme strofe samt mulighed for at karakterisere, hvad han omtaler som Grundtvigs »frie, sprogligt selvbevidste gendigtning (123). Ægidius gør det klart, at Grundtvigs Nordens Mytologi fra 1832 afstedkommer en intens beskæftigelse med Nordens Mytologi og en deraf følgende oversættelsesvirksomhed blandt Grundtvigs elever, eksempelvis hos Fr. Hammerich, hvis oversættelse præges af et forsøg på at levendegøre gamle nordiske vendinger, samt af en fuldstændig tilslutning til Grundtvigs syn på myterne som manifestationer af folkeånden $\mathrm{i}$ folkets barndom. Samme år som denne bog udkommer, udsender Ægidius et værk om den nordiske mytologi indenfor den danske højskole, et værk, der bygger på et afsluttende skriftligt universitetsarbejde. Da dette værk udkom i 1978, var det den hidtil mest omfattende, samlede fremstilling af dette vigtige stykke højskolehistorie. Sidenhen har Jens Peter Ægidius imidlertid samlet de to spor i sin forskning gennem udsendelsen af de omfangsrige og grundige værker Bragesnak 1 og Bragesnak 2. Bragesnak 1 (anmeldt i Grundtvig Studier 1985 af Vilhelm Nielsen) gør rede for Grundtvigs og de første grundtvigianeres forståelse af og brug af myterne.

Med Brage-Snak 2 skriver Ægidius en fortsættelse til sin redegørelse for Grundtvigs syn på og tolkning af den nordiske mytologi. Denne fortsættelse behandler brugen af mytologien i det 20. århundrede indenfor den mytologiske højskoletradition, af Ægidius karakteriseret som »en ganske selvbevidst, åndskraftig, varieret og ikke ubetydelig retning i det samlede danske højskolebillede og dermed i den folkelige oplysnings- og åndsvirksomhed i perioden « (210). Denne karakteristik må forekomme de fleste kendere af den mytologiske højskole rigtig. Selv om retningen langtfra dominerede højskolen $\mathrm{i}$ henseende til størrelse eller grundpræg, er det rimeligt at sige, at Aage Møllers visioner om en tilbagevenden til mytefortællingen indenfor højskolen »satte« debatten i mellemkrigstiden. Ægidius arbejder ud fra det synspunkt, at der kan tales om en tradition, der viderefører Grundtvigs egne tiltag: »det grundtvigske, som det fik sin udformning i Nordens Mytologi, 1832 og blev udbygget i Grundtvigs senere mytologiske forfatterskab« (226). Ægidius karakteriserer dette grundtvigske gennem to punkter. 1) det er afgørende, at tilgangen til myten (forstået som et geografisk bestemt, folkeligt udtryk for almenreligiøsite), finder sted gennem kristendommen, - Ægidius anfører den bibelske tanke om menneskets skabelse i Guds billede som belæg for dette; 2) myten er mundtlig, kun gennem det levende ord virker myten ind $\mathrm{i}$ og på en folkelig sammenhæng. En sådan 
indkredsning af en tradition i to punkter yder hverken Grundtvig eller den mytologiske højskole fuld retfærdighed. Det er imidlertid altid en vanskelig sag at uddestillere det væsentlige $\mathrm{i}$ en tradition, og gennem Ægidius's tekstnære, velskrevne redegørelser for det 20. århundredes »mytologiske« højskolemænd åbnes læserens blik for de forandringer, som den grundtvigske tradition nødvendigvis er undergivet i kraft af den historiske udvikling.

Ægidius indleder sin fremstilling med at tage tråden op fra den forrige bog, idet han giver en bredere bestemmelse af situationen i højskolen omkring år 1900, efter at brugen af den nordiske mytologi som grundlag for højskolens livsoplysning var blevet problematiseret omkring 1890. Således ridses baggrunden op for den skikkelse, der i vort århundrede har medvirket til, ja vel har størstedelen af æren for, at den nordiske mytologi ikke blev glemt i højskolen. Denne skikkelse er naturligvis Aage Møller, hvis portræt dominerer Bragesnak 2's forside.

Bragesnak 2 - der præges af Ægidius’s interesse for personerne i lige så høj grad som ideerne, - rummer for mig at se den bedste skildring af højskolemanden Aage Møller, der hidtil er givet. Hvor man i ny og næ kan synes, at Ægidius forfalder til alt for megen fremlæggelse af materialet uden en samlende tolkning og vurdering, tegner bogen et fint, indfølende og samtidig skarpt portræt af Aage Møllers strenge, patriarkalske personlighed og hans appel til tilhøreren, der for nærværende anmelder synes at adskille sig fra Grundtvigs lunerige, spøgende mytologiske fremstillinger $\mathrm{i}$ formen og tildels $\mathrm{i}$ indholdet. Aage Møller lever og taler ind i det 20. århundredes virkelighed, ligesom han i sin mytetolkning i langt højere grad end Grundtvig er den afgjorte forkynder.

Netop i behandlingen af Aage Møllers holdning til samtiden bevæger Ægidius sig med sund varsomhed. Det er, - forekommer det nærværende anmelder, - næppe forkert at tale om, at Aage Møller på sin egen måde, i sit opgør med det moderne gennembruds afsmitning på højskolen, på en vis måde kan siges at have haft $\mathrm{i}$ det mindste en vis lighed med de bevægelser, der på tragisk vis var medbestemmende for flere europæiske nationers skæbne i mellemkrigstiden. Ægidius medgiver da også, at der i visse artikler af Aage Møller fra 1930-ernes begyndelse er træk, der præger i den retning. Samtidig gør han det klart, at der ikke er tale om en blivende indflydelse på Aage Møllers holdninger, og han gør rede for Aage Møllers klare afvisning af samarbejdspolitikken under besættelsen, en afvisning, der deltes af Aage Møllers elever.

Om disse elever fortæller Ægidius også levende, man mærker, at han har kendt flere af dem personligt. For den, der som nærværende anmelder har fået vakt sin Grundtvig-interesse og sit engagement i Grundtvigs tanker gennem de mytologiske højskolefolks tale om mennesket og dets skæbne i perspektiv af kristendommen, men alligevel med udgangspunkt i en forståelse af mytologiens selvstændige værdi, er der meget at hente både $\mathrm{i}$ bogens fremstilling og $\mathrm{i}$ den vurderende karakteristik af højskolefolk som Poul Engberg og Folke Trier Hansen. Der ofres med fuld ret megen plads på skildringen af sidstnævnte, der med sin varme personlighed og mærkelige blanding af skarphed og åbenhed nåede ud til vide kredse med sine mytefortællinger.

Spændende er det, at Ægidius slutter sin bog med at behandle de forskellige vurderinger af Aage Møllers indsats, som fremkom i 1985, dvs. i hundredåret for hans fødsel. Nogle af de yngre højskolefolk, der har haft et forhold til den mytologiske tradition, forsøgte her at vurdere både mytologiens status og Aage Møllers indsats. Man finder her indlæg, der ud fra et sent etableret forhold til emancipationsbølgen fra 1960-ernes slutning kritiserer både Møllers patriarkalske forhold til 
kvinden og Møllers manglende forståelse for åndens og kroppens samvirken og ligeværd; men man finder også John Engelbrechts spændende vurdering, der sammenligner Aage Møllers forkyndende højskole og Møllers ungdomsvens, J.Th. Arnfreds højskole, båret af tro på voksende erkendelses frigørende magt. Det synes at være Engelbrechts pointe, at begge retninger er nødvendige for at en »hel« højskole kan blive virkelighed. Ægidius viderefører i sin kommentar disse tanker, og forbinder således sin fremstilling med overvejelser, der fra højskolens første dage har afstedkommet diskussioner om forholdet mellem livsoplysning og kundskabsmeddelelse. Selv runder Ægidius sit værk af med overvejelser, der tolker den mytologiske højskole som hjælpende med til formidling af de indsigter fra romantikken, der holder »menneskeåndens kanaler åbne til det irrationelle, til rødderne, til »bestandighedsværdierne «...« (228). Ægidius er samtidig bevidst om, at dette kun kan ske ud fra en bevidsthed om, at menneskehedens mytologiske periode er fortid og nu indgår i den arv, nutiden fører med sig. Disse betragtninger vidner om Ægidius’ førnævnte engagement $i$ det materiale, han forsker i, et engagement, der som sagt er kombineret med en enestående flid.

Jens Peter Ægidius’ forskning i nordisk filologi samt i folkehøjskolens baggrund og historie har da sidste år foreløbig givet sig udslag i en omfattende udgivelse, bogen om Rødding Højskoles stifter Chr. Flor. Bogen, - der selvfølgelig kommer i forbindelse med fejringen af højskolejubilæet, - er blevet belønnet med Christian Paulsen-prisen som den bedste besvarelse af en udskrevet prisopgave om »en videnskabeligt underbygget Christian Flor-biografi«. Af særlig interesse for Grundtvig Studiers læsere er naturligvis fremstillingen af Flors forhold til Grundtvig, men bogen fremstår som en omhyggelig, kronologisk opbygget redegørelse for Flors liv og indsats. Også i dette værk sporer vi den kombination af engageret indlevelse og flittigt arbejde med kildestoffet, der er Ægidius's særkende. Ægidius følger ved hjælp af Flors kortfattede levnedsskildring Flor fra dennes opvækst i et københavnsk borgerhjem med norske rødder gennem studietid, lærergerning og præsteembede frem til udnævnelsen til dansk lektor ved universitetet i Kiel. Her bliver kildematerialet bedre. Chr. Flor skulle i Kiel give undervisning i dansk til kommende embedsmænd i Slesvig-Holsteen, idet reskripterne af 1810 indskærpede brugen af dansk som officielt sprog i de dele af hertugdømmerne, hvor dansk var det almindelige, talte sprog. Ægidius gør rede for, hvorledes Flor af hensyn til sit giftermål ind i en højere stand af svigerfaderen blev presset til at tage doktorgraden, men sandsynligg $\varnothing r$ også, at Flor tidligt har interesseret sig for kampen for det danske sprogs overlevelse i Sønderjylland. De første år i Kiel har ikke været nemme, - her betragtede studenterne tilsyneladende ikke den krævede attest i dansk som noget, der skulle tages særlig alvorligt. Flor gav sig i kast med opgaven med flid og engagement og udgav i denne periode bl.a. en dansk læsebog, men Ægidius beskriver alligevel perioden som en ventetid, - en ventetid, der afløses af den kamp for dansk sprog og nationalitet, som Flor ifølge Ægidius fra sin ansættelse har arbejdet henimod.

Ægidius har fra begyndelsen bestræbt sig på at tegne et billede af Flor som en mand, hvis karakter prægedes af mandighed, af Ægidius bestemt som en nordisk karakteregenskab, og hvis interesse for dansk nationalitet og nordisk ånd tidligt blev vakt gennem læsning af Oehlenschlägers værker. I forbindelse med Flors forhold til Grundtvig gør sig nemlig det interessante gældende, at Flor langtfra begyndte som Grundtvig-tilhænger. I den berømte »Tylvtestrid « var Flor med blandt de 12 studenter, der stod på Oehlenschlægers side mod Baggesen. Meget lidt vides om teologen 
Flors præstegerning i tiden før lektoratet i Kiel, og det er da også karakteristisk, at det værk, der drejede Flor i Grundtvigs retning, er Grundtvigs storværk Nordens Mytologi fra 1832. Anders Pontoppidan Thyssen siger i sine omfattende kapitler fra bogen Grundtvig og grundtvigianismen $i$ nyt lys, at det kultursamarbejde mellem kristne og naturalister af ånd, som Grundtvig tilsigter i den berømte indledning til mytologien, først bliver en reel virkelighed fra 1830-ernes midte, - blandt ledende akademikere ændsedes Grundtvigs folkelige hovedskrift ikke i 1832. Flor er altså tidligt ude med sin begejstring for værket, og Ægidius viser da også, at Flors anmeldelse - der langt snarere er en loyal og pædagogisk præsentation af værket end en kritisk recension, - fjernede Flor fra de ledende københavnske akademikere, der nægtede anmeldelsen optagelse i deres blad. I stedet lod Flor den trykke som en lille selvstændig bog. Denne anmeldelse eller indføring viser Flor som den roligt fremadskridende, tekstnære fortolker af Grundtvigs værk.

Flor blev således i første omgang grebet af Grundtvigs universalhistoriske vision og tanken om en nordisk dannelse, - Flor var, som Ægidius viser, alle dage en ivrig skandinavist. Samtidig bragtes Flor i 1830-erne også til at dele Grundtvigs kirkelige anskuelse. Da det sønderjyske blad »Dannevirke« blev søsat af triumviratet Flor, P. C. Koch og Jens Christian Nissen, fremgår det af brevvekslingen mellem Koch og Flor, at Flor tilslutter sig både Grundtvigs teologiske og historiske anskuelse, »Rasks Sproglære« og »den Nordiske Treenighed, kort...Alt, hvad der udspringer af den Nordiske Aands liv« (117). Flor har med andre ord været én af de Grundtvigdisciple, der tidligst har forstået og sympatiseret med Grundtvigs tanke om forbindelsen mellem kristendom og dansk-nordisk folkelighed, båret af det levende ord som åndens legeme. Her kunne man gerne have ønsket sig, at Ægidius var gået nærmere ind på Flors Grundtvig-forståelse, der synes at være meget tæt på udgangspunktet, altså på Grundtvigs tanker (kapitlet om forfatterskabets holdninger bringer læseren et skridt videre $\mathrm{i}$ forhold til den kronologiske fremstilling, men kunne sagtens have været mere udbygget $i$ henseende til analyser af Flors grundtvigske tanker, disses forudsætninger i Flors læsning før mødet med Grundtvig og deres grad af overensstemmelse med Grundtvigs ideer). Ægidius viser, hvorledes Flors grundtvigianisme (Ægidius’s betegnelse) også isolerer ham i forhold til de københavnske nationalliberale. Men er Ægidius’s analyser af Flors synspunkter stundom noget knappe, får han til gengæld tegnet et billede af en mand, der brænder for en sag, og som med klogskab og organisatorisk talent får virkeliggjort de initiativer, han i samarbejde med sine medkæmpere har skønnet, var nødvendige for den danske sag i Slesvig. Chr. Flor er et godt eksempel på, hvorledes Grundtvigs tanker kom til at spille en rolle $\mathrm{i}$ sidste århundredes danmarkshistorie i kraft af praktiske mænd, der var i besiddelse af talegaver, og som begejstredes af de grundtvigske visioner. Flors betydning for skikkelser som Peder Hiort Lorenzen og Laurids Skau dokumenteres grundigt af Ægidius. Morsomt er det, at Ægidius godtgør, hvorledes Grundtvigs linje om abekattene i sangen »Velkommen i den grønne Lund« stammer fra Skaus tale til den berømte Skamlingsbankefest i 1843, - den tale, som Flor havde forfattet forud for festen!

Flors virke for etableringen af en folkehøjskole i Nordslesvig behandles indgående af Ægidius, der gennem citater viser, hvorledes de har deres grundlag i Grundtvigs tanker om skolen i Sorø, og at Flors geniale indsats netop var at omplante disse tanker efter tiden og omstændighederne til en lokal skole, hvor han ovenikøbet fremførte så moderne en tanke som et skoleråd bestående af lærere og elever! Dette blev dog ikke ført ud i livet, omend Flor i sin tid på Rødding oprettede en elevforening, der på lignede vis skulle opdrage til demokrati. Flors tanker om 
folkehøjskolens undervisningsform - og program viser, hvor tæt han var på Grundtvig, når det gælder forbindelsen mellem undervisning i historie og opdragelse af den almindelige borger til at tage et politisk ansvar. Ægidius skildrer, hvorledes Flor i Røddings første år måtte kæmpe med den populære, rationalistisk orienterede lærer C.M. Poulsen om skolens målsætning, - Poulsen ville trække den i praktisk-nyttig retning, Flor fastholdt sine grundtvigsk inspirerede tanker. Da Flor lod sig afløse af Fr. Helweg, tolker Ægidius den uenighed, der opstod mellem Grundtvig og Flor omkring Helwegs ansættelse, som ubetydelig, idet han i stedet fæstner sig ved, at Helweg gennem sin mytefortælling viderefører Flors begejstring for de nordiske myters plads i højskolens undervisning. Ægidius citerer Roar Skovmand for at sige, at Flor er den egentlige skaber af den mytologiske højskole. Flor, der trods grundlæggelsen af Rødding delte Grundtvigs ønske om etableringen af »Skolen i Soer«, regnede sig som sagt for Grundtvig-discipel, og det er vigtigt for Ægidius at fastslå, at han vedblev at være det, trods forhold, der kunne tydes som pegende på uenighed med den vækkelsesprægede grundtvigianisme, og dermed måske også med Grundtvig $i$ en senere fase af dennes udvikling. Det var Flor om at gøre at bevare Rødding fra, hvad han betegnede som »den énsidige Grundtvigianisme« (repræsenteret af Jakob Knudsens far Jens Lassen Knudsen, der som lærer på Rødding var tættere på Kolds højskolevisioner end Flors) ved at forbinde de nordisk-dannende fag med praktisk, nyttebetonet undervisning. Ægidius argumenterer for Flors fortsat gode forhold til den grundtvigske bevægelse og til folkehøjskolens senere udvikling ved at fremlægge materiale, der forbinder Flor med den grundtvigianisme, der får sit grundpræg fra midten af 1800-tallet. Røddings videreførelse i Askov under Schrøders ledelse havde Flors opbakning, og Flor blev vundet for Chr. Kolds person og højskolevirksomhed, trods forskellen i målsætning - Kolds oplivende virksomhed kan vanskeligt skilles fra den ensidige grundtvigianisme, Flor kritiserede. I sine sidste år havde Flor, - også uden for Danmarks grænser, - status som »folkhögskolornas oldermand «, således betegnet $\mathrm{i}$ et telegram fra Sverige.

Flors højskoleerfaringer kom i hans alderdom andre til gode. Flor var således til det sidste et virksomt menneske. Man tilslutter sig som læser gerne Ægidius’s dom, at Flor forenede idealisme og praktisk sans i sin helstøbte personlighed, karakteriseret af almindelighed forstået som jævn, ligefrem menneskelighed. Hertil kommer da yderligere den førnæunte sans for handling i rette tid og for strategisk vigtige initiativer.

Med bogen om Flor har Jens Peter Ægidius forbundet sin forskning i den nordiske mytologis status indenfor dansk åndshistorie med et stykke højskolehistorie, der er uløseligt sammenvævet med kampen for danskheden i sidste århundredes Slesvig. Det gælder om denne bog såvel som om de tidligere, at Ægidius her har givet dansk forskning og dansk højskoleliv en række værker, der ikke kan undværes i undersøgelsen af vor fortid og i den løbende debat. 